\title{
National Interlibrary Loan Code, 1968
}

\section{INTRODUCTION}

This code, adopted by the Reference Services Division, acting for the American Library Association on June 27, 1968, governs the interlibrary lending relations among libraries on the national level, among research libraries, and among libraries not operating under special or local codes. Libraries of a common geographical area or those specializing in the same field may find it advantageous to develop codes for their own needs. There is appended to this national code a model state code ${ }^{x}$ which may be considered for adoption by such groups of libraries with common interests.

On the national level interlibrary loan requests should be restricted to materials which cannot be obtained roadily and at moderate cost by other means. The costs involved in lending and the conflict in demand for certain kinds of materials necessitate this restriction.

The American Library Association has published ${ }^{2}$ a manual explaining in detail the procedures which should be used in implementing the principles of this code. Libraries requesting materials on interlibrary loan are expected to have copies of this manual and to abide by its recommendations.

The present interlibrary loan system may be radically changed by less conventional methods of transmission of materials, such as telefacsimile and computer networks. Until such methods have gained widespread acceptance, their use must be based on special agreements among libraries.

I. Definition. Interlibrary loans are transactions in which library materials are made available by one library to another for the use of an individual; for the purposes of this code they include the provision of copies as substitutes for loans of the original materials.

II. Purpose. The purpose of interlibrary loans is to make available, for research, materials not owned by a given library, in the belief that the furtherance of knowledge is in the general interest. Interlibrary loan service supplements a library's resources by making available, for the use of an individual, materials from other libraries not owned by the borrowing library.

III. Responsibility of Borrowing Libraries.

1. It is assumed that each library will provide the resources to meet the study, instructional, informational, and normal research needs of its users, and that requests for materials from another library will be limited to

\footnotetext{
1 Not included with this text but in preparation as of September 5, 1968.

"Manual in preparation and not yet published as of September 5, 1968.
}

unusual items which the borrowing library does not own and cannot readily obtain at moderate cost. Requests for individuals with academic affiliations should be limited to those materials needed for faculty and staff research, and the thesis and dissertation research of graduate students.

2. Thesis topics should be selected according to the resources on hand and should not require extensive borrowing from other libraries. If an individual needs to use a large number of items located in another library, he should make arrangements to use them at that library.

3. The borrowing library should screen carefully all applications for loans and should reject those which do not conform to this code.

IV. Responsibility of Lending Libraries.

1. In the interests of furthering research it is desirable that lending libraries interpret as generously as possible their own lending policies, with due consideration to the interests of their primary clientele.

2. A lending library has the responsibility of informing any borrowing library of its apparent failure to follow the provisions of this code.

V. Scope.

1. Any type of library matcrial needed for the purpose of research may be requested on loan or in photocopy from another library. The lending library has the privilege of deciding in each case whether a particular item should or should not be provided, and whether the original or a copy should be sent.

2. Libraries should not ordinarily ask, however, to borrow the following types of materials:

a. U.S. books in print of moderate cost

b. Serials, when the particular item needed can be copied at moderate cost

c. Rare materials, including manuscripts

d. Basic reference materials

e. Genealogical, heraldic, and similar materials

f. Bulky or fragile materials which are difficult and expensive to pack (e.g. newspapers)

g. Typescript doctoral dissertations, when fully reproduced in microfilm and readily available

VI. Expenses.

1. The borrowing library assumes the responsibility for all costs charged by the lending library, including transportation, insurance, copying, and any service charges. If the charges are more than nominal, and not authorized beforehand by the borrowing library, the lending library should inform the requesting library and ask for authorization to proceed with the transaction. Borrowing libraries should try to anticipate charges, such as for copies, 
and authorize them on the original request

2. It is recommended that in the interests of efficiency the lending library absorb costs which are nominal, such as for postage.

VII. Conditions of Loans.

1. The safety of borrowed materials is the responsibility of the borrowing library. In case of loss or damage the borrowing library is obligated to meet all costs of repair or replacement, in accordance with the preferences of the lending library.

2. The borrowing library is bound by any limitations on use imposed by the lending library. It is recommended to lending libraries that any limitations ( such as "for use in library only") be based on the physical condition or the bibliographic character of the particular item rather than be imposed on all materials lent.

3. Unless specifically forbidden by the lending library, copying by the borrowing library is permitted provided that it is in accordance with copyright law and American Library Association policy.

VIII. Placement of Requests.

1. Libraries should exhaust local resources and make an effort to locate copies through the use of bibliographical tools, union lists, and union catalogs. Requests should be made to one of the nearer institutions known to possess the desired material. Care should be taken, however, to avoid concentrating requests on a few libraries.

2 . In the absence of special agreements, requests should normally be placed by mail using the standard ALA forms, or by teletype using a format based on the ALA interlibrary loan form. When an urgent request is made by telephone, this initial request should be immediately followed by the confirming ALA form.

IX. Form of Request.

1. Materials requested must be described completely and accurately following accepted bibliographic practice.

2. Items requested should be verified and sources of verification given, and for this purpose borrowing libraries should have access to basic bibliographic tools. When the item requested cannot be verified, the statement "Cannot verify" should be included with complete information on the original source of reference. If this provision is disregarded and the bibliographic data appear to be incorrect, the request may be returned unfilled without special effort to identify the reference.

3. The name and status (position or other identifying information) of the individual for whom the material is being requested should be included on the request form.

4. A standard ALA interlibrary loan form should be used for each item requested (or an ALA photoduplication order form, when it is known that copies will be supplied and payment required).

5. All correspondence and shipments should be conspicuously labeled "Interlibrary Loan."

\section{Duration of Loan.}

1. Unless otherwise specified by the lending library, the duration of loan is normally calculated to mean the period of time the item may remain with the borrowing library, disregarding the time spent in transit.

2 . The borrowing library should ask for renewal only in unusual circumstances, and a second renewal should never be asked for without a specific explanation. The renewal request should be sent in time to reach the lending library on or before the date due. The lending library should respond to renewal requests promptly; if it does not, it will be assumed that renewal for the same length as the original loan period is granted.

3. Material on loan is subject to recall at any time and the borrowing library should comply promptly.

4. The loan period specified by the lending library should be appropriate to the type of material.

XI. Notification and Acknowledgment.

1. The lending library is expected to notify the requesting library promptly whether or not the material is being sent; if the material cannot be supplied, the lending library should state the reason.

2. Except in the case of very valuable shipments, no acknowledgment of receipt is necessary. If there is undue delay in receipt, however, the receiving library has a responsibility to notify the lending library so that a search may be initiated promptly.

XII. Violation of Code.

Continued disregard of any of the provisions of this code is sufficient reason for suspension of borrowing privileges.

\section{SENATOR HILL HONORED}

Senator Lister Hill was honored on June 20 at the National Library of Medicine by the library's Board of Regents and staff. Paying tribute to the Senator, who is retiring after over forty years of public service, were Alabama's Junior Senator, John Sparkman, who served with Mr. Hill in the Senate for more than twenty years; U.S. Department of Health, Education, and Welfare Secretary Wilbur J. Cohen; Worth B. Daniels, M.D., first chairman of the Presidentially-appointed Board of Regents of the National Library of Medicine and Mr. Hill's personal physician; colleagues from both Houses of the Congress; officials of the Department of Health, Education, and Welfare; and many other friends from the biomedical community. 